\title{
COMMENTARY
}

\section{From sickness to fitness: modernising medical certification}

The coming years herald a radical overhaul of the sickness absence certification process in the UK, under direction of the Department of Work and Pensions (DWP). Decreased productivity, days lost and the associated healthcare expenses of ill health in people of working age in the UK is estimated to cost in excess of $£ 100$ billion per annum. 'This sum is equivalent to the gross domestic product of Portugal, and is greater than the total annual running costs of the NHS. ${ }^{2}$ It is an accepted view that work can be beneficial to health. Therefore there is a move towards promoting able employees back into the workplace. This not only improves the individuals' socioeconomic wellbeing, but also aims to reduce the financial burden imposed upon society.

GPs are typically the first healthcare professionals consulted by patients who are absent from work through illness. It is recognised that the recommendations and support GPs communicate to patients and their employers via 'sick notes' is an indispensable form of medical therapy to both parties. Sick notes are there principally to allow employees time and allowance for necessary medical recuperation, but the information provided can also enable organisations to think ahead and plan their workforce in the most costeffective way.

Current sick notes, such as the 'Med-3', have remained largely unchanged for over half a century, but they have limitations. They centre on the causes of illness, rather than the consequences, and oblige doctors to impose rather rigid and arbitrary periods of sick leave. Confirming to an employer that their employee is suffering from ill health is very different to making a judgement on whether or not they are well enough to do all or some aspects of their job, and the existing system does little to assist doctors in making that decision.

Improving Health and Work: Changing Lives, ${ }^{3}$ published in November 2008, was the Government's response to Working for a Healthier Tomorrow, 'Dame Carol Black's review of the health of Britain's working age population. The key message from this publication of relevance to general practice is that the DWP has now formulated several new strategies for sick certification and in managing return to work after sick leave. ${ }^{3.4}$ These reforms include a new 'fit note' programme for GPs to improve knowledge and skills in occupational medicine.

The fit note system ${ }^{3}$ switches the focus of doctors' advice to what patients can still manage to do rather than what they can't do. This is designed to assist patients and employers in considering whether, with modified tasks and workplace adaptation, a patient's earlier return to work might be accommodated where reasonable. So far, paper and electronic versions have been tested with over 500 GPs from across the UK. This, and other 'Fit for Work' schemes, developed with the support of healthcare professionals, trade unions, and employer representatives, will roll out across Britain in spring 2010.

GPs will be at the forefront of these changes and will have a pivotal role as both the gatekeepers and evaluators of this new sick certification system.

\section{Steven E Bradshaw,}

Oxford Radcliffe Hospitals NHS Trust. E-mail: stevenb117@hotmail.co.uk

\section{Provenance}

Commissioned; not peer reviewed.

\section{REFERENCES}

1. Black C. Working for a healthier tomorrow. London: TSO, 2008. http://www.workingforhealth.gov.uk/documents/working-for-a-healthier-tomorrow-tagged.pdf (accessed 27 May 2009).

2. Bradshaw SE. Life's work: occupational health — the wealth of the nation. Br J Gen Pract 2008; 58(554): 605-606.

3. The Stationery Office. Improving health and work: changing lives. London: TSO, November 2008. http://www.workingforhealth.gov.uk/documents/large-print-improvinghealth-and-work-changing-lives.pdf (accessed 27 May 2009).

4. Department for Work and Pensions. 25 November 2008 - Keep Britain working — Johnson and Purnell respond to Dame Carol Black report. http://www.dwp.gov.uk/mediacentre/pressreleases/2008/nov/emp118-251108.asp (accessed 2 Jun 2009).

DOI: 10.3399/bjgp09X453549

6. Chartered Institute of Personnel and Development. Absence management: a survey of policy and practice. London: Chartered Institute of Personnel and Development, 2005

7. Hiscock J, Ritchie J. The role of GPs in sickness certification. Report No 148. Leeds: HMSO, 2001.

8. Hussey S, Hoddinott P, Wilson P, et al. Sickness certification system in the United Kingdom: qualitative study of views of general practitioners in Scotland. BMJ 2004; 328(7431): 88.

9. Department for Work and Pensions. Client group analysis: quarterly report on the population of working age on key benefits - February 2005. DWP: London, 2005.

http://www.dwp.gov.uk/asd/asd1/cga_wa/CGA_WA_Feb05_bulletin.pd f (accessed 26 May 2009).

10. Porcheret M, Hughes R, Evans D, et al. Data quality of general practice electronic health records: the impact of a program of assessments, feedback, and training. J Am Med Inform Assoc 2004; 11(1): 78-86.

11. Jordan K, Clarke AM, Symmons DP, et al. Measuring disease prevalence: a comparison of musculoskeletal disease using four general practice consultation databases. Br J Gen Pract 2007; 57(534): 7-14.

12. Wynne-Jones G, Mallen CD, Main CJ, Dunn KM. Sickness certification in general practice: a comparison of electronic records with selfreported work absence. Primary Healthcare Research and Development 2008; 9: 113-118. doi:10.1017/S1463423608000650.

13. NHS Information Authority. The clinical terms version 3 (the Read 